Dialectic Volume II, Issue II: Front Matter

\title{
Designing the future We Want
}

MARIANA AMATULLO, PHD ${ }^{1}$

1. The New York School/Parsons, New York, NY, USA

SUGgested CitATION: Amatullo, M. “Designing the Future We Want.” Dialectic, 2.2 (2019): pgs. 9-13.

DOI: http://dx.doi.org/10.3998/dialectic.14932326.0002.201 


\section{Designing \\ the Future We Want}

MARIANA AMATULLO, PHD

"We live not in a settled and finished world, but in one which is going on and where our main task is prospective." - John Dewey, Democracy and Education, 1916. ${ }^{1}$

Today's context for design research and practice is one of a world that is transforming at breakneck speed, and where interdependence is the name of the game. The volatile reality of the 21st century presents us with a world order that, in many ways, is incomparable to previous ones.

Technological innovations, most notably Artificial Intelligence (AI), are sweeping in a new rate of change that is profoundly transforming how work gets done, and altering how we live our lives. We are at the dawn of the fourth industrial revolution, a digitally fueled transformation where computers and robots are likely to upend the marketplace and significantly alter the fundamental nature of countless jobs, products and services that we take for granted today. ${ }^{2}$ Concurrently, natural and human-induced changes in many of the Earth's ecosystems, including vulnerabilities involving access to and the quality of health, food, water, energy and infrastructure, are challenging us to design more integrated solutions that are capable of cutting across wicked problems. The phenomenon of climate change and its negative impact on the geopolitics of a warming world is shaping up to become one of the defining challenges of the 21st century. ${ }^{3}$ Attempts to understand the cumulative effects of human activity on our planet to date have inspired a new geologic name for our time period, the Anthropocene. ${ }^{4}$ Meanwhile, in several Western democracies, we are grappling with an alarming rise of political strains of populism that are dangerously divisive and discriminatory, which poses a threat to human rights. The imperative to connect knowledge with action in order to harness a sense of common purpose and cooperation to imagine a better life for the majority of the human beings who inhabit this world has never been greater.

The past provides us only with limited blueprints on how to confront these challenges, while many of our existing conceptual frameworks are proving inadequate to cope with the intensifying processes of globalization and the severe governance problems they are generating. ${ }^{5}$ It can be easy to fall into a sense of blinding presentism, or tempting to naively look in the rearview mirror of the past to seek answers for what the future might hold.

From this vantage point of dynamic change, coupled with an increased rate of uncertainty about our possible futures, to what degree might the field of design as a generative knowledge discipline provide us with a positive way forward? In my view, this is one of the critical questions we as design educators, researchers, scholars and practitioners must face with renewed focus in order to seek principled responses filled with both creativity and rigor.

Oscar Wilde once famously quipped that all progress is the realization of utopias. ${ }^{6}$ In the field of design for social

\footnotetext{
Dewey, J. Democracy and Education. London, UK: Macmillan Publishing, 1916; North Chelmsford, MA, USA: Courier Corporation, 2004.

2 Schwab, K. The Fourth Industrial Revolution. World Economic Forum Report, 3 January 2017. Online. Available at: https://www.weforum.org/about/the-fourth-industrial-revolution-by-klaus-schwab (Accessed February 14, 2019).

3 Busby, J. "Warming World. Why Climate Change Matters More than Anything Else," Foreign Affairs, 97.4, (2018): pgs. 49-55.

4 Scranton, R. Learning to Die in the Anthropocene: Reflections on the End of a Civilization. San Francisco, CA, USA: City Lights Publishers, 2015.

5 Deudney, D. Bounding power: Republican security theory from the polis to the global village. Princeton, NJ, USA: Princeton University Press, 2016.

6 Wilde, O. The Soul of Man under Socialism and Selected Critical Prose. London, UK: Penguin UK, 1910, 2007.
} 
innovation, in which I situate my research and practice, we tend to embrace the future less as "an imaginary and indefinitely remote place" in the traditional definition of the term utopia ${ }^{7}$, and instead think of it more pragmatically, as a unique opportunity-space for agency to both adapt known solutions and to pursue the discovery of new possibilities oriented toward social change. If I have reason to be hopeful, it is because I believe that today's maturing forms of design for social innovation are inclusive of a healthy dose of criticality about the plural futures we may want to build. ${ }^{8,9}$ Not only is there a broadening and deepening of design's meanings and functions in our knowledge economy ${ }^{10}$, but we are also starting to be more purposeful about measuring the positive impact design can have in advancing social innovation outcomes and human progress. ${ }^{11}$ Moreover, we are increasingly taking an evidence-based approach to argue for design's strategic capability in coping with the rate of exponential change that is disrupting our organizations. ${ }^{12}$ There is a growing influx of design researchers and practitioners who are incorporating new knowledge from across disciplines, as well as new forms of technology, into projects that may vary in application, thematic foci and organizational scope, but that also share a commitment to actively contributing to broad societal impact. ${ }^{13}$

The question upon us then - again, as design educators, researchers, scholars and practitioners - is to ask ourselves to what extent might these gains and developments foreground new opportunities for design to operate in the future with bolder socio-cultural, political and environmental aspirations, coupled with increased legitimacy and effectiveness? And, as importantly, how might present-day designers systematically make tangible visions of alternative futures that we might harness today to influence what we create tomorrow? If we recognize that the task to explore longer-term factors and drivers of change to the future is ongoing, let us start now by endeavoring to be less entrenched in our ways of being, knowing and doing ${ }^{14}$, and truly open up to design's potential to serve as a bridging force that contributes to building a future that is tolerant and-dare I venture - celebratory of a new Global Commons that we can only dream of today.

\section{References}

Amatullo, M. "Design Attitude and Social Innovation: Empirical Studies on the Return of Design." PhD diss., Weatherhead School of Management, Case Western Reserve University, Cleveland, OH, USA, 2015). https://www.researchgate.net/ publication/282663024_Design_Attitude_and_Social_Innovation_Empirical_Studies_of_the_Return_on_Design

Amatullo, M., Boyer, B., Danzico, L., and Shea, A., eds. LEAP

Dialogues: Careers Pathways in Design for Social Innovation. Pasadena, CA, USA: Designmatters: ArtCenter College of Design, 2016.

Busby, J. "Warming World. Why Climate Change Matters More than Anything Else," Foreign Affairs, 97.4, (2018): pgs. 49-55.

Deudney, D. Bounding power: Republican security theory from the polis to the global village. Princeton, NJ, USA: Princeton University Press, 2016.

Dewey, J. Democracy and Education. London, UK: Macmillan Publishing, 1916; North Chelmsford, MA, USA: Courier Corporation, 2004.

Escobar, A. Designs for the pluriverse: radical interdependence, autonomy, and the making of worlds. Durham, NC, USA:

Duke University Press, 2018.

Julier, G. Economies of Design. Thousand Oaks, CA, USA:

Sage, 2017.

Manzini, E. Design, When everybody designs: An introduction to design for social innovation. Cambridge, MA, USA: MIT

Press, 2015 .

Merriam-Webster Dictionary. Accessed online at Merriam-webster.com: https://www.merriam-webster.com/

\footnotetext{
7 Merriam-Webster Dictionary. Accessed online at Merriam-webster.com: https://www. merriam-webster.com/dictionary/utopia?src=search-dict-box (Accessed February 17, 2019).

8 Manzini, E. Design, when everybody designs: An introduction to design for social innovation. Cambridge, MA, USA: MIT Press, 2015

9 Thackara, J. How To Thrive In The Next Economy. London, UK: Thames \& Hudson, 2017.

10 Julier, G. Economies of Design. Thousand Oaks, CA, USA: Sage, 2017.

11 Amatullo, M. "Design Attitude and Social Innovation: Empirical Studies on the Return of Design." PhD diss., Weatherhead School of Management, Case Western Reserve University, Cleveland, OH, USA, 2015). https://www.researchgate.net/publication/282663024_Design_ Attitude_and_Social_Innovation_Empirical_Studies_of_the_Return_on_Design. (Accessed May 21, 2019).

12 Yee, J., Jefferies, E., \& Michlewski, K. Transformations: 7 Roles to Drive Change by Design. Amsterdam, The Netherlands: BIS Publishers, 2017.

13 Amatullo, M., Boyer, B., Danzico, L., and Shea, A., eds. LEAP Dialogues: Careers Pathways in Design for Social Innovation. Pasadena, CA, USA: Designmatters: ArtCenter College of Design, 2016.

14. Escobar, A. Designs for the pluriverse: radical interdependence, autonomy, and the making of worlds. Durham, NC, USA: Duke University Press, 2018.
} 
dictionary/utopia?src=search-dict-box (Accessed February 17, 2019).

Schwab, K. The Fourth Industrial Revolution. World Economic Forum Report, 3 January 2017. Online. Available at: https:// www.weforum.org/about/the-fourth-industrial-revolution-by-klaus-schwab (Accessed 14 February 2019).

Scranton, R. Learning to Die in the Anthropocene: Reflections on the End of a Civilization. San Francisco, CA, USA: City Lights Publishers, 2015.

Thackara, J. How To Thrive In The Next Economy. London, UK: Thames \& Hudson, 2017.

Yee, J., Jefferies, E., \& Michlewski, K. Transformations: 7 Roles to Drive Change by Design. Amsterdam, The Netherlands: BIS Publishers, 2017.

Wilde, O. The Soul of Man under Socialism and Selected Critical Prose. London, UK: Penguin UK, 1910, 2007.

Mariana Amatullo, $P \boldsymbol{h D}$ serves as the Vice Provost for Global Strategic Initiatives in the Provost's Office at The New School in New York City, New York, USA. She is an Associate Professor of Strategic Design and Management at its School of Design Strategies, and a core faculty member of the Civic Service Design Graduate Minor that will launch in the fall of 2019.

In her role as Vice Provost, Mariana collaborates with the New School's offices of Global Partnerships, Corporate Partnerships, Curriculum and Learning, and Open Campus to co-create and lead academic strategy that involves partnership assessment and execution. She also provides high-level support and advisement to faculty and staff stakeholders on programmatic frameworks, content, evolution, and follow-up for projects undertaken by these offices.

Mariana joined The New School in August 2017 to initially serve as the co-chair of its Management initiative, a university-wide effort that seeks to develop an integrated approach to the conception and delivery of a new vision of management education for the 21st century. Prior to attaining her position at The New School, Mariana served as Vice President and faculty at ArtCenter College of Design in Pasadena, California, USA, where she co-founded and led its award-winning social innovation department, Designmatters, for sixteen years. As a practitioner-scholar, Mariana has extensive expertise conceiving, funding and managing a portfolio of international and national educational projects, research initiatives and publications at the intersection of design, design management and social innovation. Mariana is the President of Cumulus, the International Association of Universities and Colleges of Art, Design and Media, the only global association to serve art, media and design education and research.

Mariana is the lead editor of LEAP Dialogues: Career Pathways in Design for Social Innovation (Designmatters/DAP, 2016) and co-edited an open-source digest of the book: LEAP Dialogues: The Educator's Guide (Designmatters, September 2017); she is currently on the editorial team of a new publication that is compiling a survey of global design cases (Global LEAP: New Frontiers in Design for Social Innovation: GlobalLeapBook.com). Her dissertation "Design Attitude and Social Innovation: Empirical Studies of the Return on Design," establishes the first quantitative metrics in the literature that demonstrate the statistical significance of design capabilities in the context of social innovation aims. She holds a Ph.D. in Management (Designing Sustainable Systems) from the Weatherhead School of Management, Case Western Reserve University; an M.A. in Art History and Museum Studies from the University of Southern California, and a Licence en Lettres Degree from the Sorbonne University, Paris, where she also studied Art History at L'Ecole du Louvre. A native of Argentina and the child of a diplomat, Mariana grew up around the world. 